\title{
Population structure and microbial community diversity of two common tetillid sponges in a tropical reef lagoon
}

\author{
Jake Ivan P. Baquiran ${ }^{1}$, Michael Angelou L. Nada ${ }^{1}$, Niño Posadas ${ }^{1}$, Dana P. Manogan ${ }^{1}$, Patrick C. Cabaitan ${ }^{1}$, \\ Cecilia Conaco ${ }^{\text {Corresp. } 1}$ \\ ${ }^{1}$ Marine Science Institute, University of the Philippines Diliman, Quezon City, Philippines \\ Corresponding Author: Cecilia Conaco \\ Email address: cconaco@msi.upd.edu.ph
}

Sponges are predicted to dominate future reef ecosystems influenced by anthropogenic stressors and global climate change. The ecological success of sponges is attributed to their complex physiology, which is in part due to the diversity of their associated prokaryotic microbiome. However, the lack of information on the microbial community of many sponge species makes it difficult to gauge their interactions and functional contributions to the ecosystem. Here, we investigated the population dynamics and microbial community composition of two tetillid sponges identified as Cinachyrella sp. and Paratetilla sp., which are common on coral bommies in a reef lagoon in Bolinao, northwestern Philippines. The sponges ranged in size from $2.75 \pm 2.11$ to $6.33 \pm 3.98 \mathrm{~cm}$ (mean \pm standard deviation) and were found at an average density of $1.57 \pm 0.79$ to 4.46 \pm 3.60 individuals per sq. $\mathrm{m}$. on the bommies. The tetillid sponge population structure remained stable over the course of four years of monitoring. Prokaryotic communities associated with the sponges were distinct but had overlapping functions based on PICRUSt2 predictions. This convergence of functions may reflect enrichment of metabolic processes that are crucial for the survival of the tetillid sponges under prevailing conditions in the reef lagoon. Differentially enriched functions related to carbon, sulfur, fatty acid, and amino acid metabolism, cellular defense, and stress response, may influence the interactions of tetillid sponges with other biota on the bommies. 
1 Population structure and microbial community diversity of two common tetillid sponges in

\section{2 a tropical reef lagoon}

3

4 Jake Ivan P. Baquiran, Michael Angelou L. Nada, Niño Posadas, Dana P. Manogan, Patrick C.

5 Cabaitan and Cecilia Conaco*

6

7 Marine Science Institute, University of the Philippines Diliman, Quezon City, 1101, Philippines

8

9 *Corresponding author:

10 Cecilia Conaco

11 E-mail: cconaco@msi.upd.edu.ph

12

13

14

15

16

17

18

19

20

21

22 


\section{Abstract}

25

26 Sponges are predicted to dominate future reef ecosystems influenced by anthropogenic stressors 27 and global climate change. The ecological success of sponges is attributed to their complex 28 physiology, which is in part due to the diversity of their associated prokaryotic microbiome. 29 However, the lack of information on the microbial community of many sponge species makes it 30 difficult to gauge their interactions and functional contributions to the ecosystem. Here, we 31 investigated the population dynamics and microbial community composition of two tetillid 32 sponges identified as Cinachyrella sp. and Paratetilla sp., which are common on coral bommies 33 in a reef lagoon in Bolinao, northwestern Philippines. The sponges ranged in size from $2.75 \pm 2.11$

34 to $6.33 \pm 3.98 \mathrm{~cm}$ (mean \pm standard deviation) and were found at an average density of $1.57 \pm 0.79$

35 to $4.46 \pm 3.60$ individuals per sq. $\mathrm{m}$. on the bommies. The tetillid sponge population structure 36 remained stable over the course of four years of monitoring. Prokaryotic communities associated 37 with the sponges were distinct but had overlapping functions based on PICRUSt 2 predictions. This 38 convergence of functions may reflect enrichment of metabolic processes that are crucial for the 39 survival of the tetillid sponges under prevailing conditions in the reef lagoon. Differentially 40 enriched functions related to carbon, sulfur, fatty acid, and amino acid metabolism, cellular 41 defense, and stress response, may influence the interactions of tetillid sponges with other biota on 42 the bommies. 


\section{Introduction}

46

47 Sponges (phylum Porifera) are a diverse group of sessile, filter-feeding invertebrate animals. They are a major component of benthic ecosystems and are responsible for many ecological processes, such as ecosystem structuring via reef consolidation and bio-erosion (Bell, 2008). Sponges link the whole reef system through the 'sponge loop' whereby dissolved organic matter released by benthic primary producers is made available to higher trophic levels in the form of particulate detritus (de Goeij et al., 2013). Sponges are also consumed as food by some spongivores (e.g. parrotfishes, angelfishes) (Wooster, Marty \& Pawlik, 2016) and they offer refuge for juvenile commensal invertebrates (Ribeiro, Omena \& Muricy, 2003), reef fish recruits (Cabaitan, Gomez \& Yap, 2016), and other macroflora (Di Camillo et al., 2017).

Sponges are predicted to be winners under future ocean conditions brought about by the changing climate (Bell et al., 2013). Although studies to date are limited to a few species, some sponges have been shown to have lower sensitivity to elevated seawater temperature and ocean 60 acidification, while others appear to benefit from the combined effects of these stressors (Bell et

61 al., 2018). For example, sponge populations in Brazil remained stable even under elevated 62 seawater temperatures brought by the El Niño Southern Oscillation event (Kelmo et al., 2013). 63 Exposure of other sponge species to combined ocean warming and acidification showed no effect 64 on growth, survival, or secondary metabolite production (Duckworth et al., 2012). In fact, the 65 bioeroding sponge, Cliona orientalis, even exhibited increased biomass and faster bioerosion rates under these conditions (Fang et al., 2013). The tolerance of sponges to environmental adversities might be attributed to the host, as well as to their associated prokaryotic symbionts. 
68 Sponges are holobionts that are associated with a diverse array of microorganisms (Thomas et al.,

69 2016). These symbionts are essential for nutrition, immunity, defense, and reproduction of the

70 sponge host (Reiswig, 1975; Pita et al., 2018). Sponge-associated prokaryotes are predicted to have

71 the capability for a wide range of metabolic processes, including photosynthesis, nitrogen fixation,

72 ammonium oxidation, sulfate reduction, and sulfur oxidation (Hoffman et al., 2005; Pita et al.,

73 2018; Feng \& Li, 2019). The diverse microbial community in sponges may contribute to the

74 ecological adaptability and plasticity of the holobiont, allowing it to thrive even in perturbed

75 environments (Erpenbeck et al., 2016; Bang et al., 2018). However, the stability of sponge

76 microbial communities can vary among host species and under different environmental conditions.

77 For example, the microbiomes of Cymbastela stipitata and Gelliodes obtusa remained stable even

78 under eutrophication stress (Luter, Gibb \& Webster, 2014; Baquiran \& Conaco 2018). Similarly,

79 the microbiome of the Great Barrier Reef sponge, Rhopaloeides odorabile, did not change under

80 eutrophication and elevated temperature conditions (Simister et al., 2012). On the other hand,

81 raising seawater temperature past its tolerance threshold disrupted the microbiome of C. orientalis

82 (Ramsby et al., 2018). Light attenuation treatments mimicking the effect of dredging activities also

83 caused a shift in the bacterial community of phototrophic sponges but did not affect heterotrophic

84 sponges (Pineda et al., 2016).

85

86 While next-generation sequencing approaches have begun to uncover the diversity of sponge

87 associated prokaryotes, the lack of baseline data on the microbial community composition of most

88 sponge species makes it difficult to assess the interactions between microbes and their hosts, as

89 well as the functional contributions of marine sponges at larger ecological scales. This emphasizes

90 the need to better understand the diversity of sponges and sponge-associated microbes and to 
91 identify microbially-driven functions in sponges to gain a more comprehensive understanding of

92 the processes within the sponge holobiont that bear implications on ecosystem functions and

93 biogeochemical cycles.

94

95 Tetillid sponges are classified under family Tetillidae of order Tetractinellida, class

96 Demospongiae. They generally possess a globular morphology with crater-like depressions

97 (Rützler and Smith, 1992) and are commonly referred to as "moon sponges" (Chambers et al.,

98 2013; Santodomingo \& Becking, 2018). The pronounced circular configuration of their

99 megascleres, minimal basal attachment, and almost solid spicule core allow tetillid sponges to

100 inhabit environments that are influenced by frequent disturbances (Byrne, 1987). Tetillids serve as

101 important structural constituents of reef systems where they provide habitats and other functions

102 for many organisms (McDonald, Hooper \& McGuinness, 2002; Van Soest and Rutzler, 2002).

103 Tetillid sponges are a challenge to identify visually in the field, particularly for individuals from

104 closely related taxa or from cryptic sympatric populations (Szitenberg et al., 2013). However,

105 studies have shown that these sponges may be differentiated based on their distinct microbial

106 community compositions (Chambers et al., 2013; Cuvelier et al., 2014).

107

108 This present work aims to elucidate the population density, size frequency distribution, and 109 prokaryotic microbial community composition of common tetillid sponges on coral bommies in a

110 tropical reef lagoon in Bolinao, northwestern Philippines. This site is influenced by multiple

111 stressors, including rising sea surface temperatures, increased precipitation, and frequent typhoons

112 (Dado and Takahashi, 2017; Fang et al., 2006, Peñaflor et al., 2009). Nutrient loading due to

113 submarine groundwater discharge and nutrient plumes extending from a nearby mariculture zone 
114 is also a persistent condition (San Diego-McGlone et al., 2008; Senal et al., 2011; Udarbe-Walker

$115 \&$ Magdaong, 2003). The combined effect of these stressors has resulted in several bleaching

116 events that has led to reduced live coral cover (Cabaitan, Gomez \& Yap, 2016; Gurney et al.,

117 2013), yet sponges like the tetillids are prevalent in the area.

118

119

120

Materials and methods

121

122 Study site

123 The study was conducted on five coral bommies (Supplementary Fig. 1) within the lagoon of the

124 Santiago reef flat in Bolinao, northwestern Philippines (B15: 16²5'50.7'N, 11955'02.1'E; B16:

$12516^{\circ} 25^{\prime} 50.6^{\prime \prime} \mathrm{N}, \quad 119^{\circ} 55^{\prime} 07.9^{\prime \prime} \mathrm{E} ; \quad \mathrm{B} 19: \quad 16^{\circ} 25^{\prime} 47.8^{\prime \prime} \mathrm{N}, \quad 119^{\circ} 55^{\prime} 14.1^{\prime \prime} \mathrm{E} ; \quad \mathrm{B} 21: \quad 16^{\circ} 25^{\prime} 48.6^{\prime \prime} \mathrm{N}$,

$126119^{\circ} 55^{\prime 2} 21.0^{\prime} \mathrm{E}$; B22: $\left.16^{\circ} 25^{\prime} 50.2^{\prime \prime} \mathrm{N}, 119^{\circ} 55^{\prime} 24.5^{\prime} \mathrm{E}\right)$. The bommies range from 20 to $60 \mathrm{~m}$ in

127 diameter and are distributed across a distance of about $500 \mathrm{~m}$. The bommies are located about 200

$128 \mathrm{~m}$ north from a populated area on Santiago Island and about $400 \mathrm{~m}$ south of the unpopulated side

129 of Silaqui Island. To the west of the bommies is the South China Sea or West Philippine Sea while

130 to the east is the Lingayen Gulf. The bommies are $7-10 \mathrm{~km}$ from the mariculture zone in the

131 Guiguiwanen channel to the south of Santiago Island. The organic matter and nutrient-enriched

132 plume from this zone can be driven by currents around Santiago Island towards the lagoon where

133 the bommies are located (Udarbe-Walker \& Magdaong, 2003). In addition, submarine

134 groundwater discharge may be a significant source of nutrients in the reef flat (Senal et al., 2011).

135

136

Peer) reviewing PDF | (2020:01:45047:1:1:NEW 18 Mar 2020) 


\section{Field surveys}

138 A transect was laid at the base around each bommie about a meter above the sandy substrate. A 1

139 sq. m. quadrat was placed every $2 \mathrm{~m}$ along each transect. All tetillid individuals found inside each

140 quadrat were counted and photographed. Sponge sizes were determined from the images using

141 Coral Point Count with Excel extensions or CPCe (Kohler \& Gill, 2006). Field surveys were

142 conducted in May 2016, August 2017, September 2018, and July 2019. A separate field survey

143 was conducted in September 2019 where small tissue cores were taken from all tetillid sponges

144 within each quadrat to estimate the abundance of species based on their characteristic internal

145 tissue color.

147 Measurement of environmental parameters

148 Environmental parameters were collected at set points around the bommies during each field 149 survey event. A multi-parameter meter (YSI Pro2030) was used to collect information on 150 temperature, dissolved oxygen (DO), and salinity, while a pH meter (SevenGo Mettler Toledo)

151 was used to measure $\mathrm{pH}$. Total suspended solids (TSS) was determined by collecting $500 \mathrm{ml}$ of 152 seawater from the sites, which were filtered through cellulose nitrate membrane filters $(0.45 \mu \mathrm{m}$ 153 pore size, Whatman) that were then oven dried at $70^{\circ} \mathrm{C}$. The initial mass of the filter was subtracted

154 from the mass after oven drying to obtain an estimate of the TSS among sites. Sedimentation rates 155 were determined using sediment traps. The traps were deployed at the bommies at a depth of 156 around $2 \mathrm{~m}$. After 24 hours, the contents of each trap were collected onto combusted, pre-weighed

157 Whatman GF/F filters. Filters were dried at $60{ }^{\circ} \mathrm{C}$ to constant weight. Sedimentation rates were 158 computed following the methods of English, Wilkinson \& Baker (1997). To determine water 159 turbulence, 8 pre-weighed clod cards were placed at each bommie for 24 hours and the percent 
160 difference in the dry weight of the clod cards before and after deployment was computed (Doty,

161 1971).

162

163 Tetillid sponge characterization

164 The sponges were characterized in terms of external morphology. Spicule types were determined

165 by bleach digestion followed by microscopic examination (Hooper, 2003). Tissue sections were

166 prepared to examine the sponge skeleton structure. Diagnostic characters were matched to

167 descriptions in the Thesaurus of Sponge Morphology (Boury-Esnault \& Ruetzler, 1997), Systema

168 Porifera (Hooper \& Van Soest, 2002) and the work of Santodomingo \& Becking (2018) to verify

169 sponge identities.

170

171 Mitochondrial cytochrome oxidase 1 (CO1) gene sequencing was conducted to complement

172 traditional morphological characters and to facilitate species identification. Genomic DNA was

173 extracted using the PowerSoil DNA Extraction Kit (MO BIO) following the manufacturer's

174 protocol. Amplification of the CO1 gene was done using the primers LCO1490 (Folmer et al.,

175 2005) and COX1 R1 (Rot et al., 2006). The $25 \mu$ PCR mix consisted of 1x PCR buffer (20 mM

176 Tris- $\mathrm{HCl} \mathrm{pH} 8.4,50 \mathrm{mM} \mathrm{KCl}), 3 \mathrm{mM} \mathrm{MgCl}_{2}, 0.2 \mathrm{mM}$ dNTPs, $0.4 \mu \mathrm{M}$ each of forward and reverse

177 primers, 1 unit Taq DNA polymerase (Invitrogen), and $30 \mathrm{ng}$ of DNA. PCR amplification was

178 conducted on a T100 Thermal Cycler (Bio-Rad, Munich, Germany) with an initial denaturation

179 phase of $5 \mathrm{~min}$ at $94^{\circ} \mathrm{C}$, followed by 40 cycles of denaturation for $1 \mathrm{~min}$ at $94^{\circ} \mathrm{C}$, annealing for

$1801.5 \mathrm{~min}$ at $50^{\circ} \mathrm{C}$, elongation for $1.5 \mathrm{~min}$ at $72^{\circ} \mathrm{C}$, and a final elongation for $10 \mathrm{~min}$ at $72^{\circ} \mathrm{C}$ (Schuster

181 et al., 2017). Amplicons of $\sim 1500$ bp or 2000 bp were gel-purified using the PureLink Quick Gel

182 Extraction Kit (Invitrogen). Purified PCR products were sent to Macrogen Inc., South Korea, for 
183 direct sequencing. Sequences were aligned using ClustalW (Thompson, Higgins \& Gibson, 1994)

184 and trimmed using Gblocks (Castresana, 1994). Phylogenetic tree rendering using Bayesian

185 inference was done using MrBayes v3.2.7a (Ronquist et al., 2012). Other CO1 sequences were

186 obtained from Szitenberg et al. (2013).

187

188 Tissue sampling and DNA extraction

189 Six individuals each of Cinachyrella sp. and Paratetilla sp. were collected from the easternmost

190 (bommie 22) and westernmost (bommie 15) bommies in December 2016 and April 2017. These

191 bommies were selected because they were farthest away from each other. Sponge sampling was

192 conducted with permission from the Philippines Department of Agriculture Bureau of Fisheries

193 and Aquatic Resources under Gratuitous Permit No. 0125-17 and 0169-19. Sponges were sliced

194 and fragments were washed with sterile seawater to remove any foreign macroscopic debris. To

195 eliminate planktonic or loosely attached microorganisms and detritus, the cleaned fragments were

196 rinsed with sterile calcium magnesium-free seawater (CMFSW) on a platform shaker at maximum

197 speed for 10 minutes. After washing, fragments were further cut into $\sim 0.5 \mathrm{~g}$ pieces and total DNA

198 was extracted using PowerSoil DNA Extraction kit (MO BIO) following the manufacturer's

199 protocol. Quality of extracted DNA was checked by agarose gel electrophoresis and concentration

200 was determined using a Nanodrop spectrophotometer prior to $16 \mathrm{~S}$ rRNA gene sequencing. 201

202 Sequencing and microbial community analysis

203 Total genomic DNA extracted from 12 tetillid sponge samples (3 biological replicates per species

204 per timepoint) were sent to Macrogen Inc., South Korea, for sequencing on the Illumina MiSeq 205 platform. The V3-V4 region of the prokaryotic16S rRNA gene was amplified using the primers 
207 GACTACHVGGGTATCTAATCC-3') (Herlemann et al., 2011). Raw sequence data were deposited in the NCBI Sequence Read Archive and can be accessed under BioProject accession number PRJNA596898. Demultiplexed paired end reads were analyzed using QIIME2 version 2018.11 (Bolyen et al., 2019; https://docs. qiime2.org). Raw data were imported and renamed 211 according to QIIME2 sample data format Casava 1.8 paired-end demultiplexed fastq. Sequences

212 were denoised by removing chimeric sequences and correcting amplicon errors using the DADA2

213 package (Callahan et al., 2016). Based on quality plots, reads were trimmed using the following

214 parameters: $-\mathrm{p}$-trim-left- $\mathrm{f}=17 ;$ - $\mathrm{p}$-trim-left-r $=21 ;$ - $\mathrm{p}$-trunc-len-f $=290 ;$ and $-\mathrm{p}$-trunc-len-r $=250$.

215 For taxonomic assignment, a naïve Bayes classifier was trained on SILVA version 132 (Quast et 216 al., 2012; https://arb-silva.de) with reference sequences trimmed to the V3-V4 region. The trained 217 classifier was applied to the representative sequences to assign taxonomy at $97 \%$ sequence 218 identity. Sequence reads classified as chloroplast and mitochondria, as well as singletons, were 219 removed using the commands "qiime taxa filter-table" and "qiime taxa filter-seqs." Amplicon sequence variant (ASV) counts were rarefied to the smallest sample size $(20,818$ sequences) prior to computation of alpha diversity metrics, such as Observed ASVs, Shannon, and Inverse Simpson. Alpha diversity metrics were computed using phyloseq (McMurdie \& Holmes, 2013), Companion to Applied Regression (car) (Fox \& Weisberg, 2019) and Ryan miscellaneous (Rmisc) (Hope, 2013). The Bray-Curtis community distance matrix was visualized using non-metric multidimensional scaling (NMDS) in vegan (Oksanen et al., 2017). Unrarefied ASV counts were 226 used to calculate nonparametric Permutational Multivariate Analysis of Variance

227 (PERMANOVA) using the Adonis method and Analysis of Similarity (ANOSIM) using 999 228 permutations for the comparison of communities. Differentially abundant ASVs were identified 
229 using ANOVA-like differential expression (ALDEx2) analysis (Fernandes et al., 2013) with

230 Welch's t test. All R packages were implemented in RStudio version 1.2.1335 (RStudio Team,

231 2018).

232

233 Prediction of functional genes

234 Phylogenetic Investigation of Communities by Reconstruction of Unobserved States or PICRUSt2

235 (Langille et al., 2013) was used to predict functional gene abundance based on ASV taxon

236 affiliations. The software was installed as QIIME2 plugin. The commands "qiime fragment-

237 insertion sepp" and "qiime picrust2 custom-tree-pipeline" setting the --p-max-nsti to 2 were used

238 to generate functional prediction. The relative abundance profiles of predicted Kyoto Encyclopedia

239 of Genes and Genomes (KEGG) ortholog (KO) genes were visualized using metaMDS. Linear

240 discriminant analysis (LDA) of effect size or LEfSe was used to identify KOs that distinguish

241 between the two species (Segata et al., 2011). KO terms with an absolute LDA $>2.0$ and alpha $<$

2420.05 were considered discriminative features.

244 Statistics

245 All data were tested for normality using Shapiro-Wilk test and homogeneity of variances using

246 Levene's test. General Linear Models (GLM) implemented in Statistica v7 were used to examine

247 the differences in mean density of tetillid sponges among bommies and across sampling periods,

248 differences in mean density of the two species of tetillid sponge among bommies, and differences

249 in environmental conditions among bommies. Results from GLM were further tested with Tukey's

250 HSD post hoc test to see which bommies and sampling periods had significant differences.

251 Kolmogorov-Smirnov tests were conducted to examine the differences in size frequency 
252 distributions of tetillid sponges across sampling periods per bommie. Statistical difference in alpha

253 diversity between the microbial community of the two sponge groups was calculated using

254 Welch's t test. A p-value $<0.05$ was considered significant. Data visualizations were produced

255 using ggplot2 (Wickham, 2016), pheatmap, and RColorBrewer in RStudio version 1.2.1335

256 (RStudio Team, 2018).

257

258

259

\section{Results}

260

261 Distribution and size frequency of tetillid sponges on the reef bommies

262 Tetillid sponges were observed on all the bommies. The sponges were typically found covered in 263 sediments and overgrown by turf algae, or in close interaction with other types of macroalgae, 264 sponges, and corals (Supplementary Fig. 2). The average density recorded over four years of 265 monitoring ranged from $1.57 \pm 0.79$ to $4.46 \pm 3.60$ individuals per sq. m. per bommie. Sponge 266 density was significantly greater on bommies 21 and 22 than on bommies 15, 16, and 19 (Fig. 1A; 267 Tukey's HSD post hoc tests: $p<0.05$ ). There was no change in sponge density over time (GLM: $268 \mathrm{~F}=2.38, p=0.09)$ (Fig. 1A; Supplementary Table 1). The average size of the tetillid sponges ranged 269 from $2.75 \pm 2.11$ to $6.33 \pm 3.98 \mathrm{~cm}$, with very few sponges growing larger than $10 \mathrm{~cm}$ (Fig. 1B). 270 A significant increase in sponge size frequency distribution was noticeable in September 2018 on

271 all the bommies, except for bommie 15 (Fig. 1B; Supplementary Table 2). Environmental 272 parameters measured across the four bommies remained similar over the monitoring period 273 (Supplementary Table 3). 


\section{Tetillid sponge morphology and sequencing}

276 Tetillid sponges on the reef bommies were identified as Cinachyrella sp. and Paratetilla sp..

277 Cinachyrella sp. exhibited deeper hemi-spherical depressions called porocalices alternatively

278 perforated by a number of small pores, or some oscular tubes, and had yellowish inner tissues (Fig.

279 2; Supplementary Table 4). This sponge possessed spicules characterized as oxea, anatriaene,

280 protriaene, sigmaspires and microoxea. Paratetilla sp. also had narrow hemi-spherical porocalices

281 that were sometimes closed, and had brown internal tissues. This sponge possessed oxea,

282 anatriaene, protriaene, sigmaspires, and microoxea spicules, as well as triradiate symmetrical rays.

283 CO1 sequences from Cinachyrella sp. samples grouped with sequences from other Cinachyrella

284 sp. while Paratetilla sp. samples clustered closely with sequences from Paratetilla bacca

285 (Supplementary Fig. 3).

286

287 Although the two species are difficult to distinguish based on their external morphology, a survey 288 that examined internal tissue color of the sponges revealed that Cinachyrella sp. was distributed 289 on all bommies at almost similar densities and was generally more abundant than Paratetilla sp., 290 which was found at greater density only on the easternmost bommie (Fig. 1C).

\section{Diversity of tetillid sponge microbiomes}

293 Sequencing of the 16S rRNA gene V3-V4 region on the Illumina Miseq platform returned a total 294 of 2,068,178 reads. After sequence filtering, a total of 587,405 reads with an average of 48,950 \pm 295 14,495 (mean \pm standard deviation) reads per library were obtained from 12 libraries (6 296 Cinachyrella sp. and 6 Paratetilla sp. samples). 1,459 amplicon sequence variants (ASVs) were 297 identified at 97\% sequence similarity and classified into 35 phyla, 78 classes and 176 orders.

298 Rarefaction curves reached a plateau at 20,818 sequences, indicating that the sequencing effort 
299 was sufficient to cover most ASVs in each sample (Supplementary Fig. 4). No significant

300 difference was observed in terms of the number of observed ASVs per species (Fig. 3A). However,

301 Paratetilla sp. showed greater species richness and diversity compared to Cinachyrella sp., as

302 indicated by significantly greater alpha diversity values based on the Shannon (Fig. 3B) and

303 Inverse Simpson (Fig. 3C) indices.

304

305 The two sponge species possessed distinct prokaryotic microbial communities with only $11 \%$ (160

306 ASVs) of ASVs shared by both tetillids (Supplementary Fig. 5). The difference in microbial

307 community composition between the two species is apparent in the NMDS plot (Fig. 3D) and is

308 statistically supported (PERMANOVA: $\mathrm{R}^{2}=0.84118, \mathrm{p}=0.001$; ANOSIM: $\mathrm{R}=0.874$, $\mathrm{p}$-value $=$

309 0.001) (Supplementary Table 5). In contrast, no statistical difference was observed in the microbial

310 communities of sponge individuals of the same species collected at different times (Cinachyrella

311 sp., December 2016: April 2017 : PERMANOVA: $\mathrm{R}^{2}=0.35515, \mathrm{p}=0.1$; ANOSIM: $\mathrm{R}=0.4815$,

312 p-value $=0.1 ;$ Paratetilla sp., December 2016: April $2017:$ PERMANOVA: $\mathrm{R}^{2}=0.51471, \mathrm{p}=$

313 0.1; ANOSIM: $\mathrm{R}=0.814$, $\mathrm{p}$-value $=0.1$ ) or from different bommies (Cinachyrella sp., Bommie

314 15: Bommie 22 : PERMANOVA: $\mathrm{R}^{2}=0.28559, \mathrm{p}=0.3$; ANOSIM: $\mathrm{R}=0.2593$, $\mathrm{p}$-value $=0.3$;

315 Paratetilla sp., Bommie 15: Bommie 22: PERMANOVA: $\mathrm{R}^{2}=0.287, \mathrm{p}=0.4$; ANOSIM: $\mathrm{R}=$

$3160.1852, \mathrm{p}$-value $=0.4)($ Supplementary Table 5). This suggests that the microbiome associated

317 with each sponge is species-specific.

319 Differentially abundant prokaryotes in Cinachyrella sp. and Paratetilla sp.

320 The Cinachyrella sp. microbiome was dominated by members of phylum Proteobacteria $(90.28 \%)$,

321 followed by Bacteroidetes (2.30\%) and Nitrospirae (1.86\%) (Supplementary Fig. 6A). These 
322 included members of class Gammaproteobacteria (52.49\%), Alphaproteobacteria (37.02\%),

323 Bacteroidia (2.29\%) and Nitrospira (1.86\%) (Supplementary Fig. 6B). Amongst ASVs classifiable

324 to the order level, the greatest proportion were affiliated with Rhodobacterales (18.68\%),

325 Nitrosoccocales (16.09\%), Betaproteobacteriales (12.19\%), Parvibaculales (10.54\%), KI89A

326 clade (3.67\%) and Nitrospirales (1.86\%) (Fig. 3E).

327

328 On the other hand, the Paratetilla sp. microbiome was dominated by phylum Proteobacteria 329 (59.52\%), followed by Chloroflexi (17.95\%), Dadabacteria (6.68\%), Verrucomicrobia (5.32\%), 330 Actinobacteria (3.73\%), Nitrospirae (2.20\%), Patescibacteria (1.69\%) and Bacteroidetes (1.39\%)

331 (Supplementary Fig. 6A). This included members of class Gammaproteobacteria (29.53\%), 332 Alphaproteobacteria (18.26\%), Dehalococcoidia (17.84\%), Deltaproteobacteria (10.97\%), 333 Dadabacteriia (6.68\%), Verrucomicrobiae (5.32\%), Acidimicrobiia (3.68\%), Nitrospira (2.20\%),

334 Parcubacteria (1.64\%) and Bacteroidia (1.37\%) (Supplementary Fig. 6B). Amongst ASVs 335 classifiable to the order level, the greatest proportion were affiliated with the SAR202 clade 336 (17.84\%), NB1-j (9.29\%), Betaproteobacteriales (7.46\%), Dadabacteriales (6.68\%), JTB23

337 (6.11\%), Pedosphareales (5.27\%), Nitrosococcales (3.83\%), Microtrichales (3.66\%), and 338 Nitrospirales (2.20\%) (Fig. 3E).

340 Forty eight ASVs differed significantly in relative abundance between the two sponge species (Fig.

341 4) based on ALDEx2 analysis with Welch's test (p-value $<0.05$ ). These differentially abundant 342 ASVs showed no clear correlation with environmental variables at the collection site 343 (Supplementary Fig. 7). Twenty ASVs affiliated with class Gammaproteobacteria (10 ASVs), 344 Alphaproteobacteria (6 ASVs), Dadabacteriia (1 ASV), Nitrospira (1 ASV), class Nitrososphaeria 
345 under Thaumarchaeota (1 ASV), and one unclassified bacterial ASV were found at relatively

346 greater abundance in Cinachyrella sp.. On the other hand, 28 ASVs belonging to class

347 Gammaproteobacteria (8 ASVs), Alphaproteobacteria (7 ASVs), Nitrospira (3 ASVs),

348 Deltaproteobacteria (2 ASVs), Acidimicrobiia (2 ASVs), Parcubacteria (2 ASVs),

349 Dehalococcoidia (1 ASV), Dadabacteriia (1 ASV), one unclassified Proteobacteria ASV, and one

350 unclassified bacterial ASV were found at higher relative abundance in Paratetilla sp.. Different

351 ASVs of Nitrospiraceae, Betaproteobacterales EC94, Dadabacteriales, and Gammaproteobacteria

352 KI89A clade were enriched in each sponge species.

353

354 Predicted functional genes in tetillid-associated prokaryotes

355 Functional prediction was conducted using PICRUSt2, a software tool that predicts the functional 356 profile of a microbial community based on 16S rRNA sequences (Langille et al., 2013). To 357 improve accuracy of metagenome prediction, the weighted Nearest Sequenced Taxon Index 358 (NSTI) value for the analysis was set to $<2.0$ (Langille et al., 2013). NSTI reflects the relatedness 359 of prokaryotic taxa in the sample to the closest available reference genome. Lower NSTI values

$360(<2.0)$ indicate greater similarity to the reference, which results in a more precise prediction of

361 functional genes (Douglas et al. 2019). However, it is important to note that PICRUSt2 is

362 predictive and does not completely substitute for whole metagenome profiling (Langille et al., 363 2013; Weigel and Erwin, 2017). Nevertheless, it provides a starting point for understanding 364 functions potentially represented within a microbial community. 365

366 PICRUSt2 predicted a total of $6892 \mathrm{KEGG}$ ortholog $(\mathrm{KO})$ genes from the microbial communities

367 associated with the two sponge species. Of these, 6234 KOs (90.5\%) were present in both 
368 microbial communities, while $405(5.9 \%)$ were present only in the Cinachyrella sp. microbiome

369 and 253 (3.7\%) were found only in the Paratetilla sp. microbiome. The predicted KO profiles of

370 the microbial community of each sponge could be differentiated by NMDS (Fig. 5A) and these

371 differences were statistically supported (Cinachyrella sp. : Paratetilla sp., PERMANOVA: $\mathrm{R}^{2}=$

372 0.79417, $\mathrm{p}=0.003$; ANOSIM: $\mathrm{R}=1$, $\mathrm{p}$-value $=0.002)($ Supplementary Table 6$)$. LEfSe analysis

373 revealed an enrichment of KOs associated with $\mathrm{ABC}$ transporters, biosynthesis of secondary

374 metabolites, fatty acid metabolism, glutathione metabolism, microbial metabolism in diverse

375 environments, quorum sensing, sulfur metabolism, and terpenoid backbone biosynthesis in

376 Cinachyrella sp.. KOs involved in bacterial chemotaxis, biosynthesis of amino acids and

377 antibiotics, carbon fixation, citrate cycle, galactose metabolism, glycolysis/gluconeogenesis,

378 methane metabolism, and pentose phosphate pathway were enriched in Paratetilla sp. (Fig. 5B).

379

380

381

Discussion

382

383 Tetillid sponge population dynamics

384 Tetillid sponges were abundant on the coral bommies and populations were stable over the course

385 of 4 years of monitoring. The easternmost bommies (bommie 21 and 22) had the highest density

386 of sponges compared to the others. These bommies face the Lingayen Gulf and are likely to be

387 less exposed to strong wave action during typhoons. Most sponges exhibited an average diameter 388 of about 3 to $6 \mathrm{~cm}$, with very few growing to larger size. This further suggests that the sponges 389 may be affected by various physical disturbances, such as grazing or predation, strong wave action,

390 and sedimentation, all of which can limit growth or cause tissue loss or mortality. An increase in 
391 size frequency distribution was observed in 2018 on all bommies, except on bommie 15, although

392 the cause remains unknown. The dynamics of the tetillid sponge population on these bommies are

393 in contrast to that of Xestospongia muta in Florida, which showed an increase in abundance over

394 the course of 6 years due to increased recruitment owing to suitable environmental conditions

395 (McMurray, Henkel \& Pawlik, 2010).

396

397 The stable population of the tetillid sponges suggests that individuals are long-lived and slow-

398 growing. In fact, another tetillid sponge, C. cavernosa, has been found to increase in mean diameter

399 by just $0.1-0.2 \mathrm{~cm}$ per year, with specific growth rates decreasing as sponge size increases (Singh

$400 \&$ Thakur, 2015). Similarly, growth rate of settled buds of Tethya citrina decreased with sponge

401 age (Cardone, Gaino \& Corriero, 2010). Growth rates were affected by temperature, silicate

402 concentration, dissolved oxygen, and the presence of competitors (Singh \& Thakur, 2016). On the

403 bommies, tetillids were typically found interacting with or in close proximity to algae, corals, and

404 other sponges. These organisms are known to produce allelochemicals and may inhibit sponge

405 growth, similar to the reported growth-limiting effect of zoanthids on C. cavernosa (Singh \&

406 Thakur, 2016). Further studies to test the impact of other benthic reef organisms on the growth of

407 tetillid sponges remain to be conducted.

408

409 Species specificity of tetillid sponge prokaryotic microbial communities

410 The sponge-associated microbiota is host-specific (Reveillaud et al., 2014; Thomas et al., 2016).

411 The prokaryotic microbial community of Cinachyrella sp. can be distinguished from that of

412 Paratetilla sp., although these two sponges co-exist in the same biogeographic location and

413 experience similar environmental conditions. The Paratetilla sp. microbial community 
414 composition reported here is similar to what has been reported for Paratetilla in other

415 biogeographic regions, with the dominance of Proteobacteria (Alpha- and Gammaproteobacteria),

416 Chloroflexi, and Actinobacterial ASVs (Thomas et al., 2016; De Voogd et al., 2018, Cleary et al.,

417 2019). The Cinachyrella sp. microbiome from this study also showed some common ASVs with

418 other Cinachyrella microbiomes, which are dominated by Proteobacteria, Bacteroidetes,

419 Cyanobacteria, and Actinobacteria (Cleary et al., 2013; Cuvelier et al., 2014; Cleary, Polonia \&

420 De Voogd, 2018). In addition, differentially abundant bacterial taxa found in both tetillid sponges

421 have previously been reported as symbionts of other sponge species. For example, Nitrospiraceae

422 was dominant in Rhabdastrella globostellata (Steinert et al., 2016), Betaproteobacteria EC94 was

423 abundant in Callyspongia sp. (Steinert et al., 2016), and Gammaproteobacteria K189A was

424 abundant in Petrosia ficiformis (Burgsdorf et al., 2014).

425

426 The microbial community in each sponge species remained similar in samples taken during 427 different times and from different bommies. Moreover, no correlation was found between 428 differentially abundant prokaryotic taxa and measured environmental variables. This mirrors 429 findings from other studies in marine sponges that suggest that microbial communities are shaped 430 by host identity (Chambers et al., 2013; Naim et al 2014; Souza et al. 2016; Steinert et al. 2016).

431 The sponge microbiome has been shown to be stable across individuals taken from different 432 sampling locations or depths (Pita et al., 2013; Reveillaud et al 2014) and can even withstand 433 moderate pollution stress (Gantt, Lopez-Legentil \& Erwin, 2017; Baquiran \& Conaco, 2018).

435 Bacteria-bacteria interactions may play a role in structuring the sponge microbial community.

436 Some sponge-associated bacteria can inhibit the growth of other members of the community 
437 through the production of various compounds and regulatory signals (Esteves, Cullen \& Thomas,

438 2017; Gutierrez-Barranquero et al., 2017). For instance, Bdellovibrio, which is enriched in

439 Paratetilla sp., is an active predator of other microorganisms and produces compounds that attack

440 the cell walls of other bacteria (Beck et al., 2004). Other sponge-associated prokaryotes are

441 attracted to sponge host-derived compounds, indicating an active role of the microbes in initiating

442 the species-specific partnerships (Tout et al., 2017; Lurgi et al., 2019). This is supported by the

443 predicted abundance of genes related to bacterial chemotaxis in both tetillid sponge species. On

444 the other hand, bacteria with reduced genomes may exist in the community as ectosymbionts or

445 parasites, relying on the biosynthetic capabilities of the host associated microbiome (Nelson \&

446 Stegen, 2015). An example of this is Parcubacteria, which was detected in Paratetilla sp..

447

448 Predicted functions of tetillid-associated prokaryotes

449 Sponge-associated prokaryotes fulfill functions that provide important benefits to the host and can 450 also influence ecosystem health and function (Taylor et al., 2007; Bell, 2008; Thomas et al., 2010).

451 In the present study, genes critical for metabolism, defense, and stress response were predicted to 452 be present in the microbiomes associated with Cinachyrella sp. and Paratetilla sp.. Various 453 differentially abundant ASVs in the tetillid sponges were affiliated with taxa known to be involved 454 in the nitrogen cycle. Nitrifying prokaryotes that transform ammonia to nitrite, such as 455 Nitrosopumilaceae (Li et al., 2014; Feng et al., 2016), the AqS1 group of Nitrosococcaceae (Rua 456 et al., 2015; Feng \& Li, 2019), and the SAR202 clade of phylum Chloroflexi (Morris et al., 2004; 457 Mincer et al. 2007), were detected in the tetillids. Members of Nitrospira, some of which are 458 enriched in Paratetilla sp., may contribute to the conversion of nitrite into nitrate (Hentschel et al., 459 2002; Daims \& Wagner, 2018). Members of Proteobacteria and Bacteroidetes, which were also 
460 identified in the tetillids, may play a role in denitrification, which removes excess nitrate from the

461 sponge tissues (Hoffman et al., 2009; Feng \& Li, 2019). The potential co-existence of nitrification

462 and denitrification functions in the tetillid sponge microbiota suggests that affiliated prokaryotes

463 can adapt to shifts from aerobic to anaerobic conditions inside the sponge (Schlappy et al., 2010).

464 In addition to supplying the nitrogen requirements of the holobiont, nitrogen metabolism by

465 sponge-associated microbes may also benefit other biota, such as macroalgae and other organisms,

466 in the surrounding area (Davy et al., 2002).

467

468 Genes related to sulfur metabolism, including sulfur oxidation and sulfate reduction, were

469 predicted to be present in the tetillid microbiomes. These two processes may be coupled, as has

470 been demonstrated in the cold water sponge Geodia barretti (Jensen et al., 2017). Sulfur oxidation

471 is a potential mechanism for the removal of toxic metabolic end-products, such as hydrogen

472 sulfide, that are produced by the sponge host. The existence of an anoxic micro-ecosystem in the

473 tetillid sponges is further supported by the presence of sulfate-reducing bacteria (SRB), such as

474 members of Deltaproteobacteria and Dadabacteria (Wasmund, Mußmann \& Loy, 2017; Hug et al., 475 2015).

476

477 Genes in key biosynthetic pathways were predicted to be present in both tetillid sponge 478 microbiomes. The microbiome of Paratetilla sp., in particular, was enriched for genes in the 479 carbon fixation pathway, pentose phosphate pathway, galactose metabolism, glycolysis, and citrate 480 cycle. Translocation of fixed carbon to the sponge would provide a valuable source of alternative 481 nutrition for the host, analogous to photosynthates from autotrophic microbes (e.g. Cyanobacteria) 482 (Kandler et al., 2018). 
483 The Cinachyrella sp. microbiome was enriched for fatty acid metabolism genes. This suggests that

484 this species may produce a diverse array of fatty acids (Rod'kina, 2005), which could serve as a

485 potential energy store or as building blocks for bioactive compounds. The enrichment of the

486 terpenoid biosynthesis pathway in the Cinachyrella sp. microbiome further suggests an active

487 involvement in secondary metabolite production, as has been reported for other species of sponges

488 (Cleary, Polonia \& De Voogd, 2018; Steinert et al., 2019). Secretion of secondary metabolites,

489 including terpenoids, may have allelopathic effects on other organisms and may contribute to the

490 differential distribution of the two sponge species. However, a detailed assessment of the

491 secondary metabolites produced by each tetillid sponge remains to be conducted.

492

493 Genes related to antibiotic production and glutathione synthesis were also predicted to be present

494 in the Cinachyrella sp. and Paratetilla sp. microbiomes. Endozoicomonas, which is abundant in

495 Paratetilla sp., can produce quorum sensing metabolites and demonstrates antimicrobial properties

496 against potentially harmful microbes (Esteves, Cullen \& Thomas, 2017; Mohamed et al., 2008;

497 Morrow et al., 2015; Rua et al., 2014). We hypothesize that the abundance of protective genes in

498 the tetillid sponge-associated symbionts may be an adaptation to stressful conditions, such as high

499 temperatures, high sedimentation rates, and eutrophic waters, that are frequently encountered in

500 the reef lagoon.

501

502 Although the microbial community composition of the two tetillids were distinct from each other,

503 it is interesting to note that the predicted functions represented in the microbiomes were similar.

504 This observation supports the concept of functional equivalence, wherein the microbiomes of

505 phylogenetically divergent hosts that occupy similar functional niches may convergently evolve 
506 to perform similar core functions, likely through the process of horizontal gene transfer (Fan et al.,

507 2012). Functional convergence of the microbial communities in tetillid sponges indicates the

508 presence of core functions that may be critical for their health and survival on the reef, and may

509 partly explain the stability of the sponge populations on the bommies. Differentially enriched

510 functions, on the other hand, may indicate species-specific adaptations influenced by host

511 metabolism or chemistry (Cleary et al., 2015; Steinert et al., 2019).

\section{Conclusion}

515

516 In this study we identified two tetillid species, Cinachyrella sp. and Paratetilla sp., that are found 517 in abundance on coral bommies within a reef lagoon. The density and size frequency of the sponge

518 populations remained relatively stable over the course of the monitoring period of approximately

519 four years, although Cinachyrella sp. was dominant on more bommies. The sponges host distinct

520 microbial communities, supporting the idea of species-specificity of the sponge microbiome.

521 However, predicted functions represented within the microbiota of the two species present a large

522 overlap, indicating functional equivalence of the communities driven by prevailing environmental

523 conditions at the site. Nevertheless, certain functions could be distinguished as differentially

524 enriched between species, particularly pathways related to carbon, sulfur, fatty acid, and amino

525 acid metabolism, cellular defense, and stress response. These likely indicate microbiome-specific

526 adaptations to host metabolism and may influence the interactions of the sponges with other biota

527 on the bommies. Further validation of the functional profiles of the tetillid sponge-associated

528 microbiota using metagenome or metatranscriptome approaches are warranted in order to verify 
529 the genes that are present and expressed, as well as the microbial players contributing to functions

530 of interest.

531

532

533 Acknowledgments

534 The authors thank Fernando Castrence Jr., Renato Adolfo, Ronald De Guzman, Ben Jack Gabuay, 535 Robert Valenzuela, Francis Kenith Adolfo, and other staff of Bolinao Marine Laboratory for their 536 invaluable assistance in the field surveys.

537

538

539

\section{References}

540

541 Bang C, Dagan T, Deines P, Dubilier N, Duschl WJ, Fraune S, Hentschel U, Hirt H, Hulter N, 542 Lachnit T, Picazo D, Pita L, Pogoreutz C, Radecker N, Saad MM, Schmitz RA, Schulenburg 543 H, Voolstra CR, Weiland-Brauer N, Ziegler M, Bosch TCG. 2018. Metaorganisms in 544 extreme environments: do microbes play a role in organismal adaptation? Zoology 127, 1545 19 DOI 10.1016/j.zool.2018.02.004.

Baquiran JIP, Conaco C. 2018. Sponge-microbe partnerships are stable under eutrophication pressure from mariculture. Marine Pollution Bulletin, 136, 125-134 DOI:10.1016/j.marpolbul.2018.09.011.

Beck S, Schwudke D, Strauch E, Appel B, Linscheid M. 2004. Bdellovibrio bacteriovorus strains 550 produce a novel major outer membrane protein during predacious growth in the periplasm 
551

552

553

554

555

556

557

558

559

560

561

562

563

564

565

566

567

568

569

570

571

572

573

of prey bacteria. Journal of Bacteriology, 186(9), 2766-2773 DOI:10.1128/jb.186.9.27662773.2004.

Bell JJ. 2008. The functional roles of marine sponges. Estuarine, Coastal and Shelf Science, 79(3), 341-353 DOI:10.1016/j.ecss.2008.05.002.

Bell JJ, Davy SK, Jones T, Taylor MW, Webster N. 2013. Could some coral reefs become ponge reefs as our climate changes? Global Change Biology, 19, 9, 2613-2624 DOI: $10.1111 / \mathrm{gcb} .12212$.

Bell JJ, Bennett HM, Rovellini A, Webster N. 2018. Sponges to be winners under near-future climate scenarios. BioScience, 68, 966-968 DOI: 10.1093/biosci/biy142.

Bolyen E, Rideout JR, Dillon MR, Bokulich NA, Abnet CC, Al-Ghalith GA, Alexander H, Alm EJ, Arumugam M, Asnicar F, Bai Y, Bisanz JE, Bittinger K, Brejnrod A, Brislawn CJ, Brown CT, Callahan BJ, Caraballo-Rodríguez AM, Chase J, Cope EK, Da Silva R, Diener C, Dorrestein PC, Douglas GM, Durall DM, Duvallet C, Edwardson CF, Ernst M, Estaki M, Fouquier J, Gauglitz JM, Gibbons SM, Gibson DL, Gonzalez A, Gorlick K, Guo J, Hillmann B, Holmes S, Holste H, Huttenhower C, Huttley GA, Janssen S, Jarmusch AK, Jiang L, Kaehler BD, Bin KK, Keefe CR, Keim P, Kelley ST, Knights D, Koester I, Kosciolek T, Kreps J, Langille MGI, Lee J, Ley R, Liu Y-X, Loftfield E, Lozupone C, Maher M, Marotz C, Martin BD, McDonald D, McIver LJ, Melnik AV, Metcalf JL, Morgan SC, Morton JT, Naimey AT, Navas-Molina JA, Nothias LF, Orchanian SB, Pearson T, Peoples SL, Petras D, Preuss ML, Pruesse E, Rasmussen LB, Rivers A, Robeson MS, Rosenthal P, Segata N, Shaffer M, Shiffer A, Sinha R, Song SJ, Spear JR, Swafford AD, Thompson LR, Torres PJ, Trinh P, Tripathi A, Turnbaugh PJ, Ul-Hasan S, Van der Hooft JJJ, Vargas F, VázquezBaeza Y, Vogtmann E, Von Hippel M, Walters W, Wan Y, Wang M, Warren J, Weber KC, 

JG. 2019. Reproducible, interactive, scalable and extensible microbiome data science using QIIME 2. Nature Biotechnology 37: 852-857 DOI: 10.1038/s41587-019-0209-9.

577

Burgsdorf I, Erwin PM, Lopez-Legentil S, Cerrano C, Haber M, Frenk S, Steindler L. 2014. Biogeography rather than association with cyanobacteria structures symbiotic microbial communities in the marine sponge Petrosia ficiformis. Frontiers in Microbiology, 5 DOI:10.3389/fmicb.2014.00529.

Byrne AP. 1987. Darwin Harbour - hydrodynamics and coastal processes. Mangrove Monograph No. 2. Australian National University, North Australia Research Unit, Darwin. pp. 19-31.

Cabaitan PC, Gomez ED, Yap HT. 2015. The spaghetti sponge Callyspongia samarensis (Wilson, $1925)$ provides temporary habitat for reef fish recruits. Marine Biodiversity, 46(3), 541-542 DOI:10.1007/s 12526-015-0410-0.

Callahan BJ, McMurdie PJ, Rosen MJ, Han AW, Johnson AJ, Holmes SP. 2016. DADA2: highresolution sample inference from Illumina amplicon data. Nature Methods, 13, 581-583 DOI:10.1038/nmeth.3869.

Cardone E, Gaino E \& Corriero G. 2010. The budding process in Tethya citrina Sar. \& Melone (Porifera, Demospongiae) and the incidence of post-buds in sponge population maintenance. J. Exp. Mar. Biol. 389: 93-100.

Castresana J. 2000. Selection of conserved blocks from multiple alignments for their use in phylogenetic analysis. Molecular biology and evolution 17, 540-552.

Chambers K, Padovan A, Alvarez B, Gibb K.2013. Microbial signatures can help distinguish moon sponges (family Tetillidae) from Darwin Harbour, Australia. Marine and Freshwater Research, 64(8), 716 DOI:10.1071/mf12226. 
597 Cleary DF, Becking LE, De Voogd, NJ, Pires AC, Polóni AR, Egas C, Gomes NC. 2013. Habitat598 and host-related variation in sponge bacterial symbiont communities in Indonesian 599 waters. FEMS Microbiology Ecology, 85(3), 465-482 DOI:10.1111/1574-6941.12135.

600 Cleary DFR, de Voogd HJ, Polonia ARM, Freitas R, Gomes NCM. 2015. Composition and 601 predictive functional analysis of bacterial communities in seawater, sediment and sponges 602 in the Spermonde Archipelago, Indonesia. Microbial Ecology DOI: 10.1007/s00248-015603 0632-5.

604 Cleary DF, Polónia AR, De Voogd NJ. 2018. Prokaryote composition and predicted metagenomic 605 content of two Cinachyrella morphospecies and water from West Papuan marine 606 lakes. FEMS Microbiology Ecology, 94(2) DOI:10.1093/femsec/fix175.

607 Cleary D, Polónia A, Huang Y, Putchakarn S, Gomes N, De Voogd N. 2019. A comparison of 608 prokaryote communities inhabiting sponges, bacterial mats, sediment and seawater in 609 Southeast Asian coral reefs. FEMS Microbiology Ecology, 95(12) DOI: $610 \quad 10.1093 /$ femsec/fiz169.

611 Cuvelier ML, Blake E, Mulheron R, McCarthy PJ, Blackwelder P, Thurber RL, Lopez JV. 2014. 612 Two distinct microbial communities revealed in the sponge Cinachyrella. Frontiers in 613 Microbiology, 5:581 DOI:10.3389/fmicb.2014.00581.

614 Dado JMB, Takahashi HG. 2017. Potential impact of sea surface temperature on rainfall over 615 the western Philippines. Prog Earth Planet Sci 4, 23 DOI: 10.1186/s40645-017-0137-6.

616 Daims H \& Wagner M. 2018. Nitrospira. Trends in Microbiology, 26(5), 462-463 617 DOI:10.1016/j.tim.2018.02.001. 
618 Davy SK, Trautman DA, Borowitzka MA, Hinde R. 2002. Ammonium excretion by a symbiotic 619 sponge supplies the nitrogen requirements of its rhodophyte partner. Journal of $620 \quad$ Experimental Biology, 205, 3505-3511.

621 De Goeij JM, Van Oevelen D, Vermeij MJ, Osinga R, Middelburg JJ, De Goeij AF, Admiraal W. 622 2013. Surviving in a Marine Desert: The Sponge Loop Retains Resources Within Coral $623 \quad$ Reefs. Science, 342(6154), 108-110 DOI:10.1126/science.1241981.

624 De Voogd NJ, Gauvin-Bialecki A, Polónia AR, Cleary DF. 2018. Assessing the bacterial communities of sponges inhabiting the remote western Indian Ocean island of Mayotte. Marine Ecology, 39(6), e12517 DOI:10.1111/maec.12517.

627

628

629

630

631

632

633

634

635

636

637

638

639

640

Di Camillo CG, Cerrano C, Romagnoli T, Calcinai B. 2016. Living inside a sponge skeleton: the association of a sponge, a macroalga and a diatom. Symbiosis, 71(3), 185-198 DOI:10.1007/s13199-016-0426-7.

Doty, M. S. 1971. Measurement of water movement in reference to benthic algal growth. Botanica Marina 14:32-35.

Douglas GM, Maffei VJ, Zaneveld J, Yurgel SN, Brown JR, Taylor CM, Huttenhower C, Langille MGI. 2019. PICRUSt2:An improved and extensible approach for metagenome inference. bioRxiv DOI: 10.1101/672295.

English S, Wilkinson C, Baker V. 1997. Survey manual for tropical marine resources. $2^{\text {nd }}$ edition. Australian Institute of Marine Science, Townsville.

Erpenbeck D, Voigt O, Al-Aidaroos AM, Berumen ML, Büttner G, Catania D, Guirguis AN, Paulay G, Schätzle S, Wörheide G. 2016. Molecular biodiversity of Red Sea demosponges. Marine

Pollution

Bulletin, 105(2),

$507-514$

DOI:10.1016/j.marpolbul.2015.12.004. 
641 Esteves AI, Cullen A, Thomas T. 2017. Competitive interactions between sponge-associated 642 bacteria. FEMS Microbiology Ecology, fix008 DOI:10.1093/femsec/fix008.

643 Fan L, Reynolds D, Liu M, Stark M, Kjelleberg S, Webster NS, Thomas T. 2012. Functional 644 equivalence and evolutionary convergence in complex communities of microbial sponge 645 symbionts. Proc. Natl. Acad. Sci. U. S. A. 109, E1878-E1887 DOI:10.1073/pnas.1203287109.

647 Fang G, Chen H, Wei Z, Wang Y, Wang X, Li C. 2006. Trends and interannual variability of the South China Sea surface winds, surface height, and surface temperature in the recent decade. Journal of Geophysical Research 111(C11):C11S16 DOI 10.1029/2005jc003276.

Fang JKH, Mello-Athayde MA, Schonberg CHL, Kline DI, Hoegh-Guldberg O, Dove S. 2013. 651 652 Sponge biomass and bioerosion rates increase under ocean warming and acidification. Global Change Biology, 19,12 DOI: doi: 10.1111/gcb.12334.

653 Feng G, Sun W, Zhang F, Karthik L, Li Z. 2016. Inhabitancy of active Nitrosopumilus-like 654 ammonia-oxidizing archaea and Nitrospira nitrite-oxidizing bacteria in the sponge Theonella swinhoei. Scientific Reports 6:24966 DOI: 10.1038/srep24966.

656 Feng G, Li Z. 2019. Carbon and Nitrogen Metabolism of Sponge Microbiome. Symbiotic 657 Microbiomes of Coral Reefs Sponges and Corals, 145-169 DOI:10.1007/978-94-024-1612658 1_9.

Fernandes AD, Macklaim JM, Linn TG, Reid G, Gloor GB. 2013. ANOVA-Like Differential 660 Expression (ALDEx) Analysis for Mixed Population RNA-Seq. PLoS ONE, 8(7), e67019

661 DOI:10.1371/journal.pone.0067019.

662 Folmer O, Black M, Hoeh W, Lutz R, Vrijenhoek R. 1994. DNA primers for amplification of 663 mitochondrial cytochrome c oxidase subunit I from diverse metazoan invertebrates. 
Molecular Marine Biology and Biotechnology, 3, 294-299.

665 Fox J, Weisberg S. 2019. An R Companion to Applied Regression, Third edition. Sage, Thousand 666 Oaks CA. Available at https://socialsciences.mcmaster.ca/jfox/Books/Companion/ $667 \quad$ (accessed 26 August 2019)

668 Gantt SE, López-Legentil S, Erwin PM. 2017. Stable microbial communities in the sponge 669 Crambe crambe from inside and outside a polluted Mediterranean harbor. FEMS 670 Microbiology Letters, 364(11) DOI:10.1093/femsle/fnx105.

671 Gurney GG, Melbourne-Thomas J, Geronimo RC, Aliñ o PM, Johnson CR. 2013. Modelling Coral 672 Reef Futures to Inform Management: Can Reducing Local-Scale Stressors Conserve Reefs 673 under Climate Change? PLoS ONE 8(11): e80137 DOI:10.1371/journal.pone.0080137.

674 Gutiérrez-Barranquero JA, Reen FJ, Parages ML, McCarthy R, Dobson AD, O'Gara F. 2017. 675 Disruption of N-acyl-homoserine lactone-specific signalling and virulence in clinical 676 pathogens by marine sponge bacteria. Microbial Biotechnology, 12(5), 1049-1063 DOI:10.1111/1751-7915.12867.

Herlemann DP, Labrenz M, Jürgens K, Bertilsson S, Waniek JJ, Andersson AF. 2011. Transitions in bacterial communities along the $2000 \mathrm{~km}$ salinity gradient of the Baltic Sea. The ISME Journal, 5(10), 1571-1579 DOI:10.1038/ismej.2011.41.

681 Hoffman F, Larsen O, Thiel V, Rapp HT, Pape T, Michaelis W, Reitner J. 2005. An Anaerobic 682 World in Sponges. Geomicrobiology Journal, 22:1-2, 1-10 DOI: $10.1080 / 01490450590922505$.

Hoffman F, Radax R, Woebken D, Holtappels M, Lavik G, Rapp HT, Schlappy M, Schleper C, 685 Kuypers M. 2009. Complex nitrogen cycling in the sponge Geodia barretti. Environ. Microbiol. 11, 2228-2243 DOI:10.1111/j.1462-2920. 2009.01944.x. 
687 Hooper JA. 2003. 'Sponguide': Guide to Sponge Collection and Identification. Available at 688 http://www.qmuseum.qld.gov.au/ naturewelcome[:sponges", (Version 2003).

689 Hooper JNA, Van Soest RWM. 2002. Systema Porifera: a guide to the classification of Sponges. $690 \quad$ Kluwer Academic Plenum Publishers, New York:1708 pp.

691 Hope RM. 2013. Rmisc: Ryan Miscellaneous. R package version 1.5. Available online at. 692 https://github.com/ CRAN.R-project.org/package=Rmisc.

693 Hug LA, Thomas BC, Sharon I, Brown CT, Sharma R, Hettich RL, Wilkins MJ, Singh A, 694 Banfield JF. 2015. Critical biogeochemical functions in the subsurface are associated with 695 bacteria from new phyla and little studied lineages. Environmental Microbiology, 18(1), 696 159-173 DOI:10.1111/1462-2920.12930

697 Jensen S, Fortunato SAV, Hoffman F, Hoem S, Rapp HT, Ovreas L, Torsvik V. 2017. The relative 698 abundance and transcriptional activity of marine sponge-associated microorganisms 699 700 emphasizing groups involved in sulfur cycle. Microbial Ecology 73, 668-676 DOI 10.1007/s00248-016-0836-3.

701

702

703

704 705

706 707

708 709

Kandler NM, Wahab MA, Noonan SH, Bell JJ, Davy SK, Webster NS, Luter HM. 2018. In situ responses of the sponge microbiome to ocean acidification. FEMS Microbiology Ecology DOI:10.1093/femsec/fiy205.

Kohler KE, Gill SM. 2006. Coral Point Count with Excel extensions (CPCe): A Visual Basic program for the determination of coral and substrate coverage using random point count methodology. Computers \& Geosciences, 32(9),

$1259-1269$ DOI:10.1016/j.cageo.2005.11.009.

Langille MG, Zaneveld J, Caporaso JG, McDonald D, Knights D, Reyes JA, Clemente J, Burkepile D, Vega Thurber R, Knight R, Beiko RG, Huttenhower C. 2013. Predictive 
710 functional profiling of microbial communities using $16 \mathrm{~S}$ rRNA marker gene 711 sequences. Nature Biotechnology, 31(9), 814-821 DOI:10.1038/nbt.2676.

712 Luter, HM, Gibb K, Webster NS. 2014. Eutrophication has no short-term effect on the Cymbastela 713 stipitata holobiont. Frontiers in Microbiology 5, 216 DOI: 10.3389/ fmicb.2014.00216.

714 Li Z, Wang Y, He L, Zheng H. 2014. Metabolic profiles of prokaryotic and eukaryotic 715 communities in deep-sea sponge Neamphius huxleyi indicated by metagenomics. Scientific 716 Reports, 4(1) DOI:10.1038/srep03895.

717 Lurgi M, Thomas T, Wemheuer B, Webster NS, Montoya JM. 2019. Modularity and predicted 718 functions of the global sponge-microbiome network. Nature Communications, 10(1) DOI:10.1038/s41467-019-08925-4.

720

721

722

723

724

725

726

727

728

729

730

731

McDonald JI, Hooper JN, McGuinness KA. 2002. Environmentally influenced variability in the morphology of Cinachyrella australiensis (Carter 1886) (Porifera : Spirophorida : Tetillidae). Marine and Freshwater Research, 53(1), 79 DOI:10.1071/mf00153.

McMurdie PJ, Holmes S. 2013. phyloseq: An R Package for Reproducible Interactive Analysis and Graphics of Microbiome Census Data. PLoS ONE, 8(4), e61217 DOI:10.1371/journal.pone.0061217.

McMurray SE, Henkel TP, Pawlik JR. 2010. Demographics of increasing populations of the giant barrel sponge Xestospongia mutain the Florida Keys. Ecology 91, 560-570.

Mincer TJ, Church MJ, Taylor LT, Preston C, Karl DM, DeLong EF. 2007. Quantitative distribution of presumptive archaeal and bacterial nitrifiers in Monterey Bay and the North Pacific Subtropical Gyre. Environmental Microbiology 9(5), 1162-1175 DOI: 10.1111/j.1462-2920.2007.01239.x . 
732 Mohamed N, Cicirelli EM, Kan J, Chen F, Fuqua C, Hill RT. 2008. Diversity and quorum-sensing

733 signal production of Proteobacteria associated with marine sponges. Environmental $734 \quad$ Microbiology 10: 75-86.

735 Morris, RM, Rappe MS, Urbach E, Connon SA, Giovannoni SJ. 2004. Prevalence of the 736 Chloroflexi- related SAR202 bacterioplankton cluster throughout the mesopelagic zone and 737 deep ocean. Appl Environ Microbiol 70: 2836-2842.

738 Morrow KM, Bourne DG, Humphrey C, Botte ES, Laffy P, Zaneveld J, Uthicke S, Fabricius KE, Webster NS. 2015. Natural volcanic $\mathrm{CO}_{2}$ seeps reveal future trajectories for host-microbial associations in corals and sponges. The ISME Journal 9, 894-908.

741

742

743

744

745

746

747

748

749

750

751

752

Naim MA, Morillo JA, Sørensen SJ, Waleed AA, Smidt H, Sipkema D. 2014. Host-specific microbial communities in three sympatric North Sea sponges. FEMS Microbiology Ecology, n/a-n/a DOI:10.1111/1574-6941.12400.

Nelson WC, Stegen JC. 2015. The reduced genomes of Parcubacteria (OD1) contain signatures of a symbiotic lifestyle. Frontiers in Microbiology, 6 DOI:10.3389/fmicb.2015.00713.

Oksanen J, Guillaume Blanchet FG, Friendly M, Kindt R, Legendre P, McGlinn D, Minchin PR, O’Hara RB, Simpson GL, Solymos P, Stevens MHH, Szoecs E, Wagner H. 2017. Vegan: community ecology package. $\mathrm{R}$ package version 2.4-3. Available online at. https://github.com/vegandevs/vegan.

Peñaflor EL, Skirving WJ, Strong AE, Heron SF, David LT. 2009. Sea-surface temperature and thermal stress in the Coral Triangle over the past two decades. Coral Reefs 28, 841-850 DOI 10.1007/s00338-009-0522-8. 
753 Pineda M, Strehlow B, Duckworth A, Doyle J, Jones R, Webster NS. 2016. Effects of light

754 attenuation on the sponge holobiont- implications for dredging management. Scientific

755 Reports, 6:39038. DOI: 10.1038/srep39038.

756 Pita L, Rix L, Slaby BM, Franke A, Hentschel U. 2018. The sponge holobiont in a changing ocean:

757 from microbes to ecosystems. Microbiome, 6(1). DOI:10.1186/s40168-018-0428-1.

758 Pita L, Turon X, López-Legentil S, Erwin PM. 2013. Host rules: spatial stability of bacterial 759 communities associated with marine sponges (Ircinia spp.) in the Western Mediterranean 760 Sea. FEMS Microbiology Ecology, 86(2), 268-276. DOI:10.1111/1574-6941.12159.

761 Quast C, Pruesse E, Yilmaz P, Gerken J, Schweer T, Yarza P, Peplies J, Glöckner FO. 2012. The 762 SILVA ribosomal RNA gene database project: improved data processing and web-based 763 tools. Nucleic Acids Research, 41(D1), D590-D596 DOI:10.1093/nar/gks1219.

764 Ramsby BD, Hoogenboom MO, Whalan S, Webster NS. 2018. Elevated seawater temperature 765 disrupts the microbiome of an ecologically important bioeroding sponge. Molecular 766 Ecology, 27, 2124-2137 DOI: 10.1111/mec.14544.

Reiswig HM.1975. Bacteria as food for temperate-water marine sponges. Canadian Journal of 768 Zoology, 53(5), 582-589 DOI:10.1139/z75-072.

Reveillaud J, Maignien L, Eren AM, Huber JA, Apprill A, Sogin ML, Vanreusel A. 2014. Hostspecificity among abundant and rare taxa in the sponge microbiome. The ISME Journal, 8(6), 1198-1209 DOI:10.1038/ismej.2013.227.

Ribeiro SM, Omena EP, Muricy G. 2003. Macrofauna associated to Mycale microsigmatosa 773 (Porifera, Demospongiae) in Rio de Janeiro State, SE Brazil. Estuarine, Coastal and Shelf Science, 57(5-6), 951-959 DOI:10.1016/s0272-7714(02)00425-0. 
775 Rod'kina SA. 2005. Fatty acids and other lipids of marine sponges. RussJ Mar Biol 31(1):S49$776 \quad$ S60.

777 Ronquist F, Teslenko M, Van der Mark P, Ayres DL, Darling A, Höhna S, Larget B, Liu L, 778 Suchard MA, Huelsenbeck JP. 2012. MrBayes 3.2: Efficient bayesian phylogenetic inference and model choice across a large model space. Systematic Biology, 61(3), 539-542 DOI: $\underline{10.1093 / \text { sysbio/sys029. }}$.

781 Rot C, Goldfarb I, Ilan M, Huchon D. 2006. Putative cross-kingdom horizontal gene transfer in sponge (Porifera) mitochondria. BMC Evol Biol.,6:71 DOI: https://doi.org/10.1186/1471783 2148-6-71.

784

785

786

787

788

789

790

791

792

793

794

795

796

797

RStudio Team. 2018. RStudio: Integrated Development for R. RStudio, Inc., Boston, MA. Available online at. http://www.rstudio.com/.

Rua CPJ, Trindade-Silva AE, Appolinario LR, Venas TM, Garcia GD, Carvalho LS, Lima A, Kruger R, Pereira RC, Berlinck RG, Valle RA, Thompson CC, Thompson F. 2014. Diversity and antimicrobial potential of culturable heterotrophic bacteria associated with the endemic marine sponge Arenosclera brasiliensis. PeerJ 2: e419.

Rua CP, Gregoracci GB, Santos EO, Soares AC, Francini-Filho RB, Thompson F. 2015. Potential metabolic strategies of widely distributed holobionts in the oceanic archipelago of St Peter and St Paul (Brazil). FEMS Microbiol Ecol. 91:fiv043.

Rützler K, Smith KP. 1992. Guide to western Atlantic species of Cinachyrella (Porifera: Tetillidae). Proceedings of the Biological Society of Washington, 105, 148- 164.

San Diego-McGlone ML, Azanza RV, Villanoy CL and Jacinto GS. 2008. Eutrophic waters, algal bloom, and fish kill in fish farming areas in Bolinao, Pangasinan, Philippines. Marine Pollution Bulletin 57, 295-301. DOI: 10.1016/j.marpolbul.2008.03.028. 
798 Santodomingo N, Becking L. 2018. Unravelling the moons: review of the genera Paratetilla and

799 Cinachyrella in the Indo-Pacific (Demospongiae, Tetractinellida, Tetillidae). ZooKeys 791:

$800 \quad$ 1-46 DOI:10.3897/zookeys.791.27546.

801 Schlappy M, Schottner SI, Lavik G, Kuypers MMM, de Beer D, Hoffmann F. 2010. Evidence of 802 nitrification and denitrification in high and low microbial abundance sponges. Marine 803 Biology 157, 593-602 DOI 10.1007/s00227-009-1344-5.

804 Schuster A, Lopez JV, Becking LE，Kelly M， Pomponi SA，Wörheide G， Erpenbeck D, 805 Cárdenas P. 2017. Evolution of group I introns in Porifera: new evidence for intron mobility 806 and implications for DNA barcoding. BMC Evolutionary Biology, 17(1) DOI:10.1186/s12862-017-0928-9.

808 Segata N, Izard J, Waldron L, Gevers D, Miropolsky L, Garrett WS, Huttenhower C. 2011. 809 Metagenomic biomarker discovery and explanation. Genome Biology 12:R60. DOI: $810 \quad 10.1186 / \mathrm{gb}-2011-12-6-\mathrm{r} 60$.

811 Simister R, Taylor MW, Tsai P, Webster N. 2012. Sponge-microbe associations survive high 812 nutrients and temperatures. PLoS ONE, 7(12), e52220 DOI: 10.1371/journal.pone.0052220.

813 Singh A \& Thakur NL. 2015. Field and laboratory investigations of budding in the tetillid sponge 814 Cinachyrella cavernosa. Invertebrate Biology, 134 (1), 19-30. doi:10.1111/ivb.12074.

815 Singh A \& Thakur NL. 2016. Influence of spatial competitor on the growth and regeneration of 816 the marine sponge Cinachyrella cf. cavernosa (Porifera, Demospongiae). Hydrobiologia 768 (1),111-123 DOI: 10.1007/s10750-015-2535-3.

818 Souza DT, Genuário DB, Silva FS, Pansa CC, Kavamura VN, Moraes FC, Taketani RG, Melo IS. 819 2016. Analysis of bacterial composition in marine sponges reveals the influence of host 
phylogeny and environment. FEMS Microbiology Ecology, 93(1), fiw204

821 DOI:10.1093/femsec/fiw204.

822 Steinert G, Taylor MW, Deines P, Simister RL, De Voogd NJ, Hoggard M, Schupp PJ. 2016. In 823 four shallow and mesophotic tropical reef sponges from Guam the microbial community 824 largely depends on host identity. PeerJ, 4, e1936 DOI:10.7717/peerj.1936.

825 Steinert G, Wemheuer B, Janussen D, Erpenbeck D, Daniel R, Simon M, Brinkhoff T, Schupp PJ. 826 2019. Prokaryotic Diversity and Community Patterns in Antarctic Continental Shelf 827 Sponges. Frontiers in Marine Science 6:297. DOI: 10.3389/fmars.2019.00297.

828 Strand R, Whalan S, Webster NS, Kutti T, Fang JKH, Luter HM, Bannister RJ. 2017. The response 829 of a boreal deep-sea sponge holobiont to acute thermal stress. Scientific Reports, 7;1660 $830 \quad$ DOI: $10.1038 / \mathrm{s} 41598-017-01091-\mathrm{x}$.

831 Szitenberg A, Becking LE, Vargas S, Fernandez JCC, Santodomingo N, Wörheide G, Ilan M, 832 Kelly M, Huchon D. 2013. Phylogeny of Tetillidae (Porifera, Demospongiae, Spirophorida) 833 based on three molecular markers. Molecular Phylogenetics and Evolution. 834 DOI:10.1016/j.ympev. 2013.02.018.

835 Taylor M, Radax R, Steger D, Wagner M. 2007. Sponge-associated microorganisms: evolution, 836 ecology, and biotechnological potential. Microbiology and Molecular Biology Review 71, 837 295-347 DOI:10.1128/MMBR.00040-06.

838 Thomas T, Rusch D, DeMaere MZ, Yung PY, Lewis M, Halpern A, Heidelberg KB, Egan S, 839 Steinberg PD, Kjelleberg S. 2010. Functional genomic signatures of sponge bacteria reveal 840 unique and shared features of symbiosis. ISME J. 4, 1557-1567 DOI: 841 10.1038/ismej.2010.74. 
842 Thomas T, Moitinho-Silva L, Lurgi M, Björk JR, Easson C, Astudillo-García C, Olson JB, Erwin

843 PM, López-Legentil S, Luter H, Chaves-Fonnegra A, Costa R, Schupp PJ, Steindler L, 844 Erpenbeck D, Gilbert J, Knight R, Ackermann G, Victor Lopez J, Taylor MW, Thacker RW, 845 Montoya JM, Hentschel U, Webster NS. 2016. Diversity, structure and convergent evolution 846 of the global sponge microbiome. Nat. Commun. 7, 11870 DOI:10.1038/ncomms11870.

847 Thompson JD, Higgins DG, Gibson TJ. 1994. CLUSTAL W: improving the sensitivity of 848 progressive multiple sequence alignment through sequence weighting, position-specific gap 849 penalties and weight matrix choice. Nucleic acids research 22, 4673-4680.

850 Tout J, Astudillo-García C, Taylor MW, Tyson G W, Stocker R, Ralph PJ, Seymour JR, Webster 851 NS. 2017. Redefining the sponge-symbiont acquisition paradigm: sponge microbes exhibit 852 chemotaxis towards host-derived compounds. Environmental Microbiology Reports, 9(6), 853 750-755 DOI:10.1111/1758-2229.12591.

854 Turon M, Caliz J, Triado-Margarit X, Casamayor EO, Uriz MJ. 2019. Sponges and their 855 microbiomes show similar community metrics across impacted and well-preserved reefs. Frontiers in Microbiology, 10,1961 DOI: 10.3389/fmicb.2019.01961.

857 Udarbe-Walker MJ, Magdaong E. 2003. Circulation and hydrographic characteristics of a 858 mariculture area northwest of Lingayen Gulf. Philipp. Sci. 40, 57-72.

859 Van Soest RWM, Rutzler K. 2002. Family Tetillidae Sollas, 1886. In: Hooper JNA, van Soest 860 RWM (eds.) Systema Porifera: a guide to the classification of sponges. Kluwer $861 \quad$ Academic/Plenum Publishers, New York. pp 85-98.

862 Wasmund K, Mußmann M, Loy A. 2017. The life sulfuric: microbial ecology of sulfur cycling in 863 marine sediments. Environmental Microbiology Reports, 9(4), 323-344 DOI:10.1111/17582229.12538. 
865 Wooster MK, Marty MJ, Pawlik JR. 2016. Defense by association: Sponge-eating fishes alter the

866 small-scale distribution of Caribbean reef sponges. Marine Ecology, 38(2), e12410 $867 \quad$ DOI: $10.1111 /$ maec. 12410.

868

869 
Figure 1

Sponge population dynamics.

(A) Tetillid sponge population density on the coral bommies from 2016 to 2019. (B) Size frequency distribution of tetillids on the bommies. Bommie 16 was not included in the May 2016 survey. (C) Distribution of Cinachyrella sp. and Paratetilla sp. on the bommies based on a survey conducted in September 2019.

A

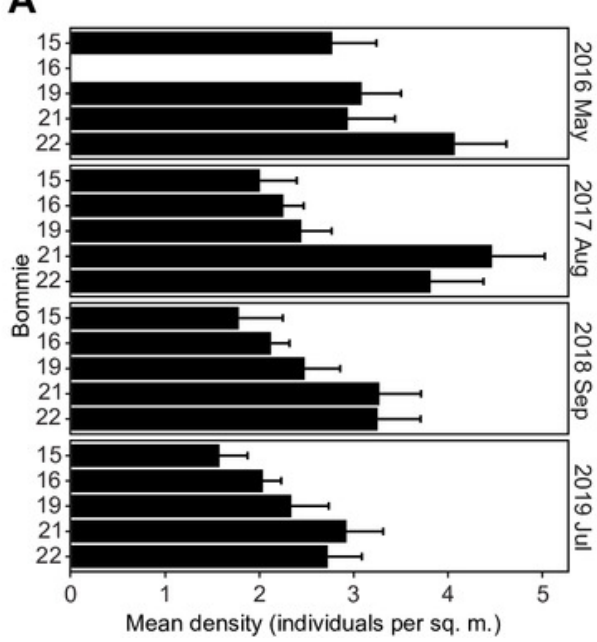

B
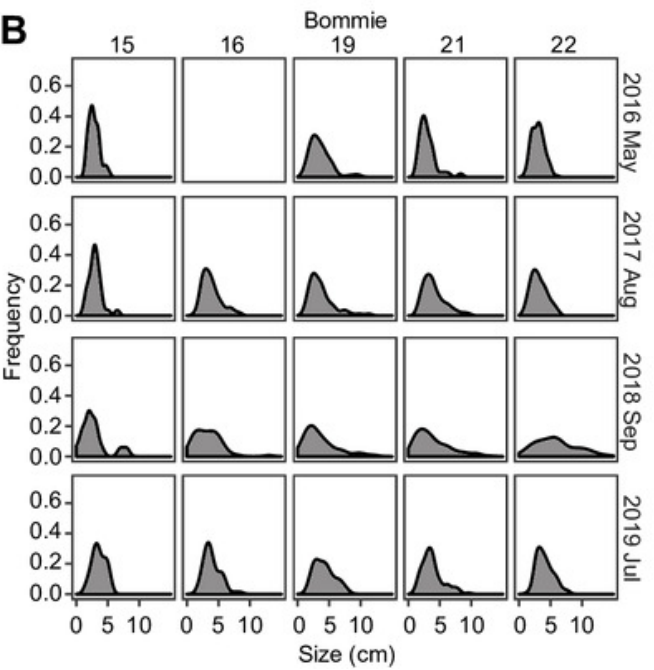

C

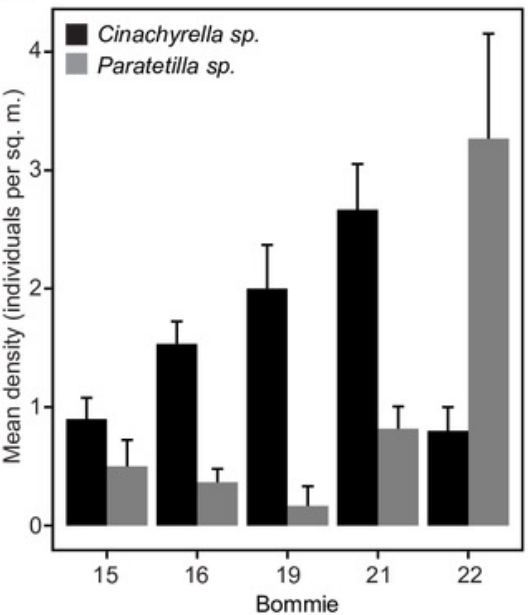




\section{Figure 2}

External morphology of Cinachyrella sp. (A) and Paratetilla sp. (B).

Hand-cut sections (insets) reveal the internal tissue color characteristic of each species.

Spicules present in the tetillid sponges include megacleres oxea (C), anatriaene (D), protriaene $(E)$, triradiate symmetrical rays $(F)$, microscleres microxea $(G)$, $c$-sigma $(H)$, and ssigma (I).
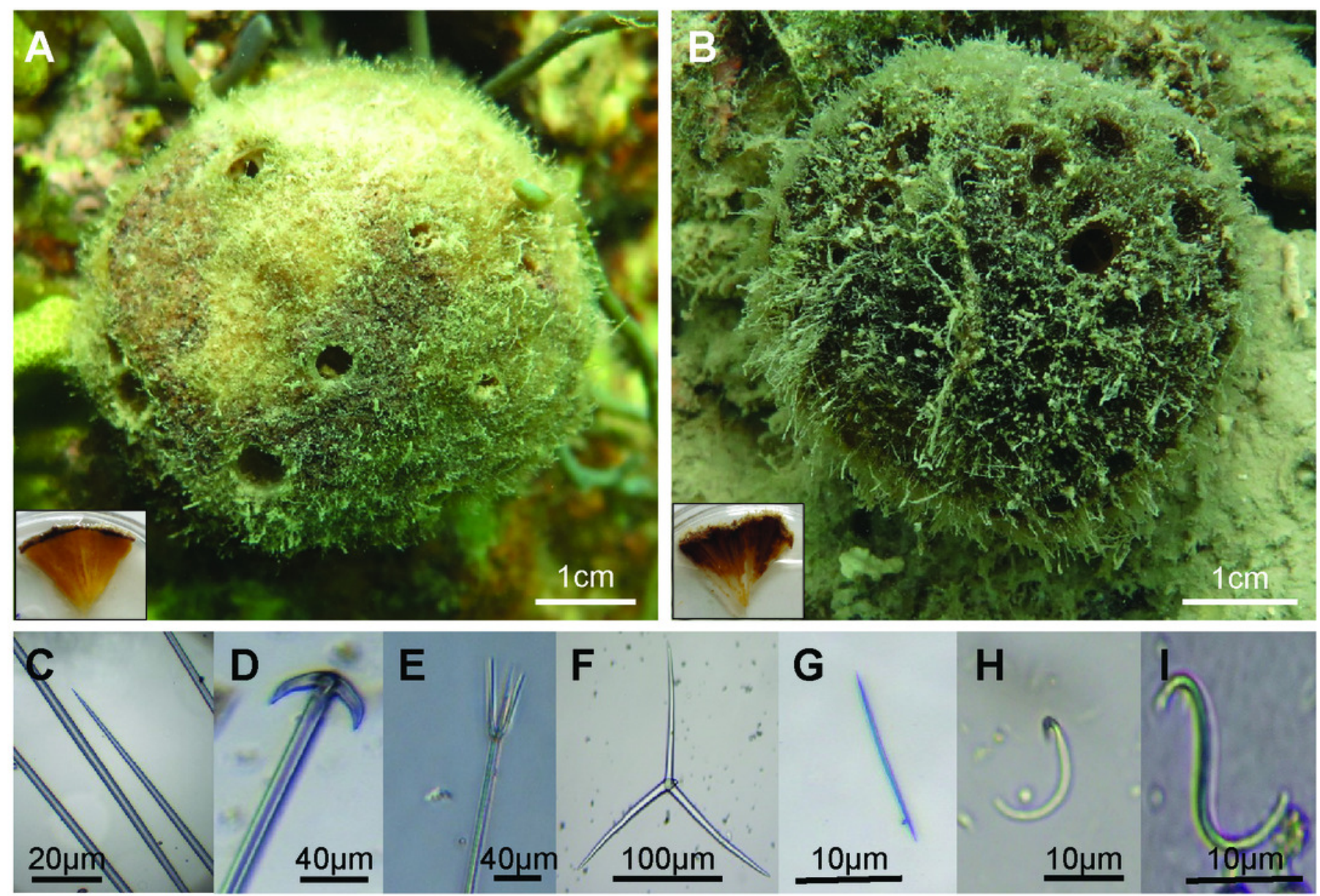

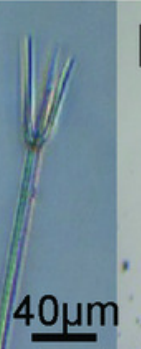

$\mathbf{F}$
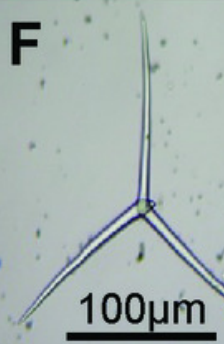
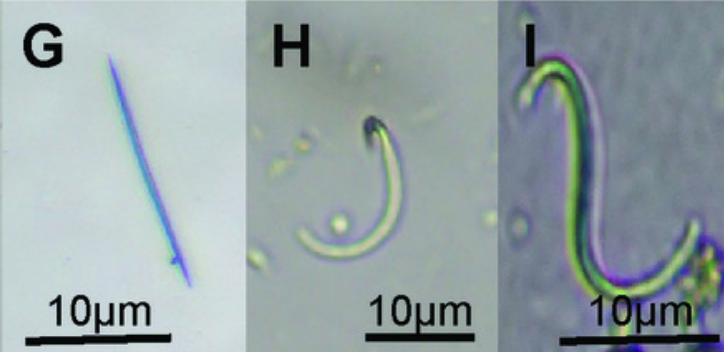


\section{Figure 3}

Microbial community characteristics of the two tetillid sponges.

Comparison of alpha diversity indices including (A) observed ASVs, (B) Shannon and (C) Inverse Simpson between sponge microbial communities in the two tetillid sponge species.

(D) Non-metric multidimensional scaling (NMDS) illustrating dissimilarity of microbial communities in Cinachyrella sp. and Paratetilla sp. individuals collected at different times (circle, Dec 2016; triangle, Apr 2017) and from different bommies (shaded, bommie 15; unshaded, bommie 22). The dashed ovals represent the $95 \%$ confidence area for each species. (E) Taxonomic assignments at order level showing the relative abundance of the $16 \mathrm{~S}$ rRNA gene sequences of microbes associated with the two sponge species collected at different times from different bommies. Orders representing less than $0.4 \%$ of the total community are represented as "other microbial orders." Colored bars represent the relative abundance of microbial taxa in each replicate sample. 

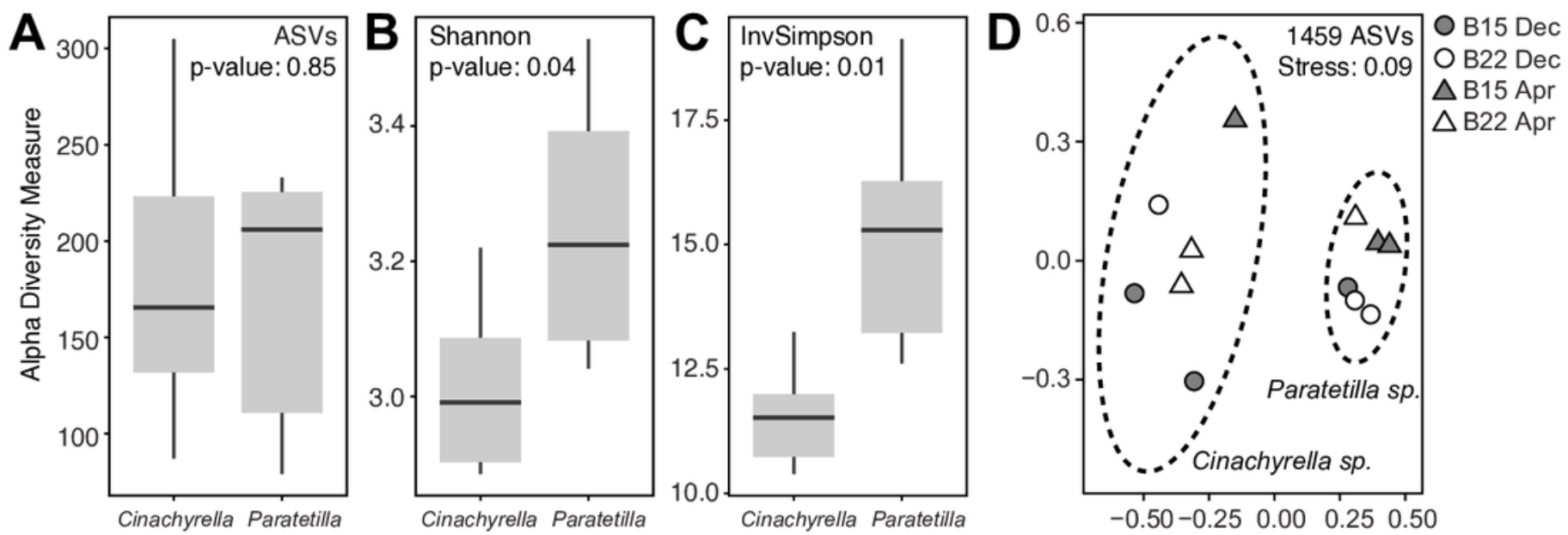

E

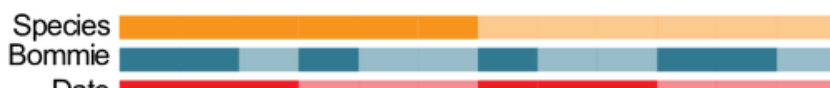

Date

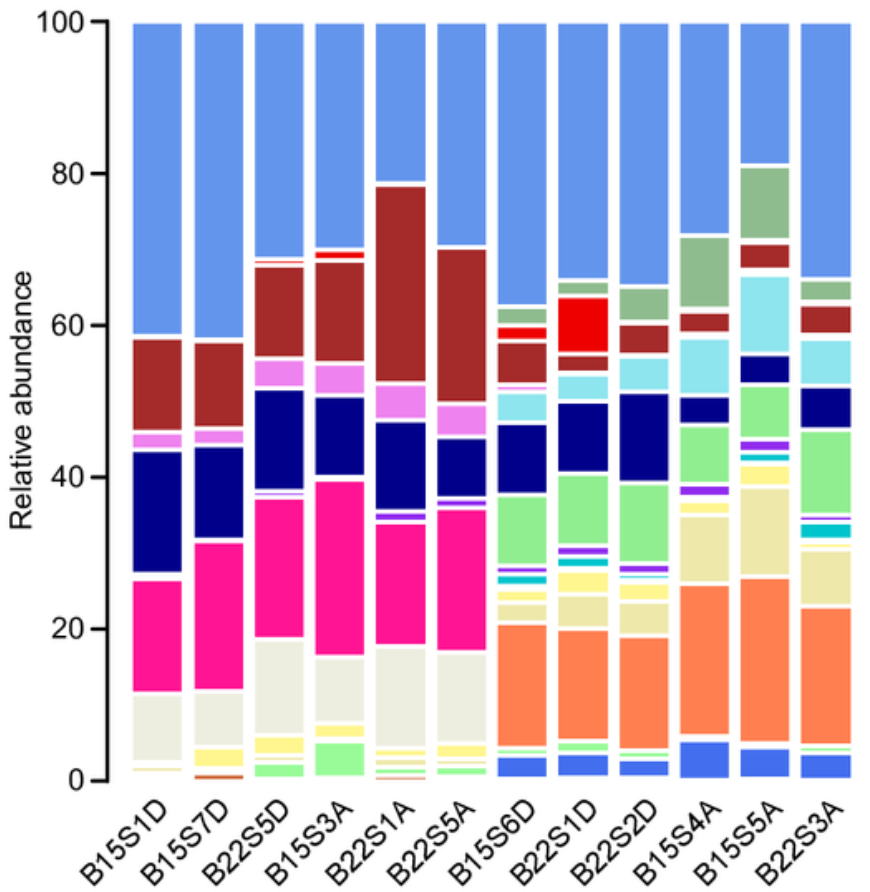

Cinachyrella sp. Bommie $15 \square$ Dec 2016

Paratetilla sp. $\quad$ Bommie $22 \square$ Apr 2017

Other microbial orders

Verrucomicrobia; Verrucomicrobiae; Pedosphaerales

Proteobacteria; Gammaproteobacteria; Oceanospirillales

Proteobacteria; Gammaproteobacteria; Nitrosococcales

Proteobacteria; Gammaproteobacteria; KI89A clade

Proteobacteria; Gammaproteobacteria; JTB23

Proteobacteria; Gammaproteobacteria; Betaproteobacteriales

Proteobacteria; Deltaproteobacteria; NB1-j

Proteobacteria; Deltaproteobacteria; Bdellovibrionales

Proteobacteria; Alphaproteobacteria; Rhodospirillales

Proteobacteria; Alphaproteobacteria; Rhodobacterales

Proteobacteria; Alphaproteobacteria; Parvibaculales

Nitrospirae; Nitrospira; Nitrospirales

Dadabacteria; Dadabacteriia; Dadabacteriales

Chloroflexi; Dehalococcoidia; SAR202 clade

Bacteroidetes; Bacteroidia; Flavobacteriales

Actinobacteria; Acidimicrobiia; Microtrichales

Thaumarchaeota; Nitrososphaeria; Nitrosopumilales 
Figure 4

Scaled heatmap of 48 differentially abundant microbial ASVs based on ALDEX2 analysis ( $p$-value $<0.05$ ). Colors represent row z-scores of each microbial taxon (red, high; blue, low). 


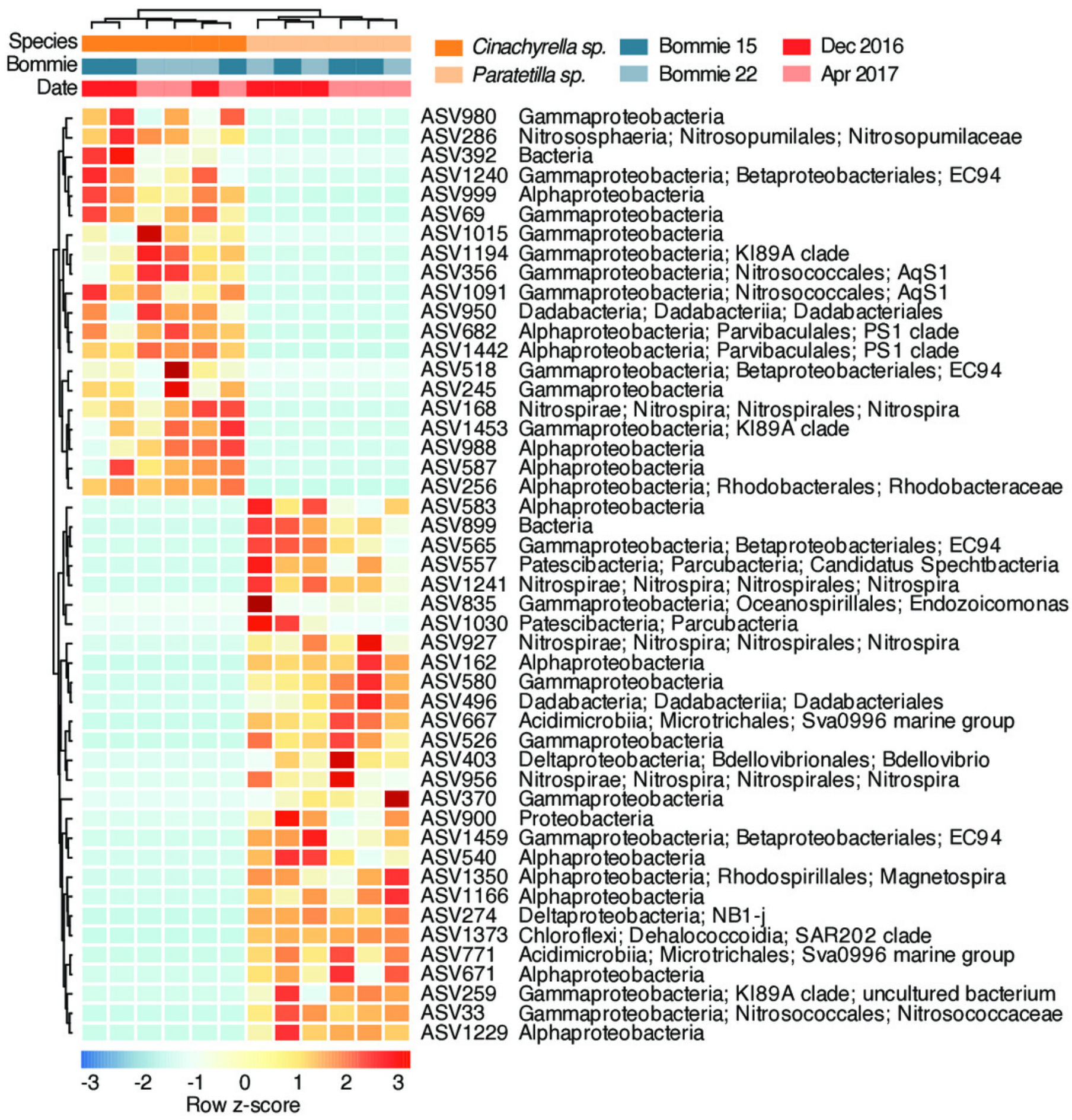




\section{Figure 5}

Functional gene predictions.

(A) Non-metric multidimensional scaling (NMDS) plot illustrating dissimilarity of the relative abundance profiles of PICRUSt2-predicted KEGG ortholog (KO) genes in the microbial communities associated with Cinachyrella sp. and Paratetilla sp. individuals collected at different times (circle, Dec 2016; triangle, Apr 2017) and from different bommies (shaded, bommie 15; unshaded, bommie 22). The dashed ovals represent the $95 \%$ confidence area for each species. (B) Average sums of the relative abundance of KOs in selected pathways. Only differentially enriched KOs in either species with LEfSe LDA $>2.0$ and p-value $<0.05$ were included.
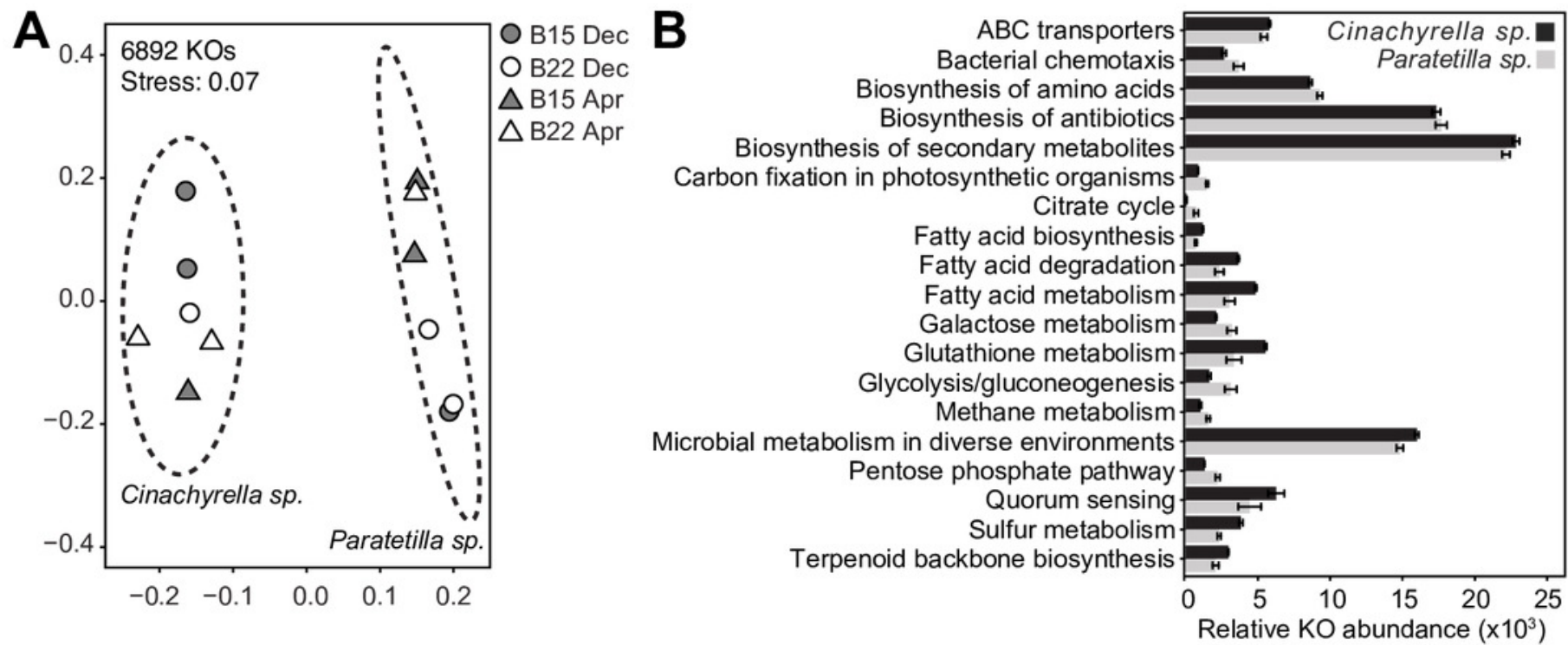